\title{
Yield Performance of Locally Selected Cocoa Clones in North Luwu
}

\author{
Agung Wahyu Susilo ${ }^{(*)}$, Indah Anita-Sari ${ }^{1)}$, and $\operatorname{Imran}^{2)}$ \\ ${ }^{1)}$ Indonesian Coffee and Cocoa Research Institute, J1. PB. Sudirman 90 Jember 68118 Indonesia \\ ${ }^{2}$ Extension Services for Forestry and Estate Crops of North Luwu District Masamba, South Sulawesi Indonesia \\ ${ }^{*}$ Corresponding author: soesiloiccri@yahoo.co.id \\ Received: 26 June 2015 / accepted: 15 August 2015
}

\begin{abstract}
Participatory selection in North Luwu District has selected some local cocoa clones, of which MCC 01 and MCC 02 are the most promising to be developed as clonal materials. This research has the objective to study stability yield performance of these clones that enable be characterized of their potency as the basis for recommendation. Observation was carried out in 35 selected-farms be differentiated according to clone type, namely MCC 01, MCC 02 and Sulawesi 01 (control) and year of planting. These farms were establised at the main area of cocoa in North Luwu. The assessed variables were number of pods, yield components, resistance to cocoa pod borer (CPB), vascular-streak dieback (VSD) and phytophthora pod rot (PPR). Data were recorded through 20 sampled-trees per farm in the period of April 2013 to April 2014 with monthly basis assessment. Data were analyzed according to Eberhart \& Russel method to perform stability parameters of the yield. The results indicated that these clones were stable in performing yield potency among plant age. MCC 01 and MCC 02 performed yield potency of 3,682 kg/ $\mathrm{ha} / \mathrm{yr}$ and $3,132 \mathrm{~kg} / \mathrm{ha} / \mathrm{yr}$, respectively higher, than Sulawesi 01 of 2,772 kg/ha/yr. MCC 01 was moderate resistance to CPB and VSD and resistance to PPR, however MCC 02 was resistance to CPB, VSD and PPR. Referring to that potency, MCC 01 and MCC 02 were legally recommended as clonal materials for farmers, restricted at the agroclimatic area similar to the condition in North Luwu.
\end{abstract}

Keywords: local variety, cocoa clones, yield performance, North Luwu, Theobroma cacao L.

\section{INTRODUCTION}

Sulawesi is well known as the center of cocoa production area in Indonesia which contributes more than $50 \%$ of national production (Ditjenbun, 2012). The highest contribution to the production derived from South Sulawesi specially produced in Luwu region. Cocoa plays significant role on economic growth in South Sulawesi, whereas its contribution to gross domestic product was the second highest after nickel. Besides, cocoa significantly contributes to household earning for about 300.000 families. Cocoa sustainability is the main issue on stabilizing economic growth in South
Sulawesi, however there are some problems which cause yield loss. The main problems on cocoa plantation in South Sulawesi are pests and diseases, decreasing soil fertility and plant aging.

Some cooperative efforts between farmers and government in addressing the problems by rehabilitating the unproductive trees using side grafting method has been carried out. Recommended clones for side grafting are Sulawesi 01 and Sulawesi 02 which are adaptive in the agro-climatic condition of Sulawesi and resistant to vascular-streak dieback (VSD). Side grafting and implementation of good agricultural practices (GAP) increased cocoa productivity fantastically 
which promoted farmers to adopt this technique. This program was initiated since early 2000's (Susilo \& Suhendi, 2006) which then broaden the scope of this rehabilitation program after Indonesia Government launched a program of the national movement to increase cocoa productivity and quality known as GERNAS program. Through this program, unproductive trees were rehabilitated using side grafting method in the area of 245,000 ha or covering $15.1 \%$ of the total cocoa area in Indonesia (Ditjenbun, 2008).

Success story on the cocoa rehabilitation using high yielding clones has triggered some innovative farmers, especially in North Luwu District to identify promising trees derived from hybrid seedlings then propagated clonally to select high yielding genotypes. Criteria of the farmer's selection are based on the yield components and resistance to endemic pests and diseases, such as VSD, cocoa pod borer (CPB) and Phytophthora pod rot (PPR). The local genetic materials of cocoa which mostly be planted in Sulawesi were derived from hybrid seedlings through a project in 1980's. The hybrids were generated from outcrossing between the selected clones as parents such as TSH 858, TSH 908, Sca 06, Sca 12, IMC 67, UIT 1, ICS 60, Pa 300, Pa 310, GC 29 (Susilo et al., 2013) from which many genetic recombinations were inherited for selection. Participaroty selection to select the best progenies can be carried out in collaboration with farmers, extention officers and breeders as the implementation of recurrent selection (Pokoe et al., 2009). Susilo (2013) identified at least 6 locally selected clones in North Luwu that had been developed by farmers for clonal materials. Of those clones, there are 2 most-preferred clones which perform high yielding, big-bean size and more tolerant to endemic pests and diseases, namely M01 and 45 as their clone codes. Those clones have been registered as local variety authorized by the Government of North Luwu District then renamed with MCC 01 and MCC 02, respectively. The utilization of these clones as clonal materials until outside North Luwu area confirms the high potency of these genetic resources to be developed as an agricultural technology suitable for farmers whith similar agroclimate condition.

Factually in the field those clones are performing high yielding potency and more tolerance to endemic pest and diseases that mostly preferred by farmers as clonal material other. Although the two clones perform higher yielding potency than the previously recommended clones of Sulawesi 01 and Sulawesi 02, they are not yet formally recommended as cocoa planting materials. A research to study yield performance of MCC 01 and MCC 02 was carried out through a collaboration research between Indonesian Coffee and Cocoa Research Institute (ICCRI) and the Government of North Luwu District in order to fulfill the requirement procedure for releasing the locally selected clones as planting material. This paper discusses the results of the yield potency study of MCC 01 and MCC 02 compared with other released clones and justified for being recommended as cocoa planting material.

\section{MATERIALS AND METHODS}

The tested cocoa clones were the two most preferred locally selected clones in North Luwu District, namely MCC 01 (clone code M01), MCC 02 (clon code 45) and Sulawesi 01 used as control (a released cocoa clone based on Degree of Ministry of Agriculture No.694/Kpts/SR.120/12/2008). The clones of MCC 01 and MCC 02 were registered as local variety authorized by the Government of North Luwu District with the registration number of No.54/PVL/2013 and No.55/PVL/2013 respectively and the historical background of which was reported by Susilo (2013). 
Yield performance observations were carried out through the selected farms in the North Luwu District area. It was situated in the low land area (maximum $300 \mathrm{~m}$ above sea level), type A-B of climatic condition according to the classification of Schmidt \& Ferguson (2 dry-months, 7-9 wet-months), type of soil Ultisol, Inceptisol, Enstisol. The sampled farms were differentiated according to the clone's type (MCC 01, MCC 02 and Sulawesi 01), year of planting/grafting (plant age) and repetition of the similar condition of the farms as replications. Thirty five farms were selected distributed through the Sub District of Masamba, Malangke, Baebunta, Tanalili, Sukamaju, Mappedeceng and Sabbang (Table 1). Year of planting varied from 2006 to 2012 when the plants were propagated by side grafting or top grafting. In each of the sampled farm 20 normal trees were selected for assessing the yield component (pod number, number of beans per pod, and dry bean weight), incidence of VSD, CPB and PPR. All of the selected farms were managed according to the farmer's management and classified as good farms.

Yield potency of the clones were assessed based on number of pods per tree in monthly basis then converted to yield potency per hectare (population of cocoa trees was assumed 1,100 trees/ha) in the period of April 2013 to March 2014. Yield data are the convertion of pod number divided by pod index which is number of pods required to produce one kilogram of dry beans. Bean count which is number of beans per $100 \mathrm{~g}$ of dry bean at $7 \%$ moisture content and number of bean per pod were needed to support yield data.

Fat analysis was conducted in the laboratory for cocoa quality of PT. Mars Symbioscience in Makassar. The method used a spectrophotometer with infra red (Foss System II 6500 scanning spectro-
Table 1. The observed farms for evaluation the yield stability performance of MCC 01 and MCC 02 in North Luwu, South Sulawesi

\begin{tabular}{|c|c|c|c|}
\hline $\begin{array}{l}\text { Farm location } \\
\text { (village, sub } \\
\text { district) }\end{array}$ & Farmer names & Clone & $\begin{array}{l}\text { Year of } \\
\text { planting }\end{array}$ \\
\hline Tingkara-Malangke & Andi Muliadi & $\mathrm{MCC} 02$ & 2006 \\
\hline $\begin{array}{l}\text { Ujung Matajang- } \\
\text { Mappedeceng }\end{array}$ & Mindarwis & MCC 01 & 2007 \\
\hline Tingkara-Malangke & Abd Rahim & MCC 01 & 2007 \\
\hline $\begin{array}{l}\text { Ujung Matajang- } \\
\text { Mappedeceng }\end{array}$ & Mindarwis & Sulawesi 01 & 2007 \\
\hline Pombakka-Masamba & Muh. Hazlan & MCC 01 & 2008 \\
\hline Bungadidi-Tanalili & Marsuki & MCC 01 & 2008 \\
\hline Tingkara-Malangke & Abd Rahim & MCC 01 & 2008 \\
\hline Putemata-Malangke & Sanuddin & MCC 02 & 2008 \\
\hline $\begin{array}{l}\text { Sumber Wangi- } \\
\text { Mappedeceng }\end{array}$ & Andi Farida & MCC 02 & 2008 \\
\hline Bungadidi-Tanalili & Rahman & MCC 02 & 2008 \\
\hline $\begin{array}{l}\text { Sumber Wangi- } \\
\text { Mappedeceng }\end{array}$ & Andi Farida & Sulawesi 01 & 2008 \\
\hline Bungadidi-Tanalili & Marsuki & Sulawesi 01 & 2008 \\
\hline $\begin{array}{l}\text { Polejiwa- } \\
\text { Malangke Barat }\end{array}$ & Kahariman & Sulawesi 01 & 2008 \\
\hline Pongo-Masamba & Idin Rasyid & MCC 01 & 2009 \\
\hline $\begin{array}{l}\text { Ujung Matajang- } \\
\text { Mappedeceng }\end{array}$ & Lamang & MCC 01 & 2009 \\
\hline \multicolumn{2}{|c|}{ Sumber Baru-Sukamaju Ambar } & MCC 01 & 2009 \\
\hline $\begin{array}{l}\text { Banyuwangi- } \\
\text { Sukamaju }\end{array}$ & $\begin{array}{c}\text { Rubiyanti/ } \\
\text { Dulkarim }\end{array}$ & MCC 02 & 2009 \\
\hline Bungadidi-Tanalili & Marsuki & MCC 02 & 2009 \\
\hline Pongo-Masamba & Kabir & MCC 02 & 2009 \\
\hline $\begin{array}{l}\text { Banyuwangi- } \\
\text { Sukamaju }\end{array}$ & $\begin{array}{l}\text { Rubiyanti/ } \\
\text { Dulkarim }\end{array}$ & MCC 01 & 2009 \\
\hline Pongo-Masamba & Idin Rasyid & Sulawesi 01 & 2009 \\
\hline $\begin{array}{l}\text { Ujung Matajang- } \\
\text { Mappedeceng }\end{array}$ & Lamang & Sulawesi 01 & 2009 \\
\hline $\begin{array}{l}\text { Banyuwangi- } \\
\text { Sukamaju }\end{array}$ & $\begin{array}{l}\text { Rubiyanti/ } \\
\text { Dulkarim }\end{array}$ & Sulawesi 01 & 2009 \\
\hline Pongo-Masamba & Salim & MCC 01 & 2010 \\
\hline Palandan-Baebunta & Sarwan & MCC 01 & 2010 \\
\hline Bungadidi-Tanalili & Marsuki & MCC 01 & 2010 \\
\hline Palandan-Baebunta & Halim & MCC 02 & 2010 \\
\hline Palandam-Baebunta & Irja & MCC 02 & 2010 \\
\hline Polewali-Baebunta & Hasrul Amir & MCC 02 & 2010 \\
\hline Karianggo-Baebunta & Beddu Jamma & Sulawesi 01 & 2010 \\
\hline $\begin{array}{l}\text { Sumber Baru- } \\
\text { Sukamaju }\end{array}$ & Ambar & Sulawesi 01 & 2010 \\
\hline $\begin{array}{l}\text { Ujung Matajang- } \\
\text { Mappedeceng }\end{array}$ & Herman & Sulawesi 01 & 2010 \\
\hline $\begin{array}{l}\text { Ujung Matajang- } \\
\text { Mappedeceng }\end{array}$ & Herman & MCC 02 & 2011 \\
\hline $\begin{array}{l}\text { Pekendekan- } \\
\text { Sabbang }\end{array}$ & Dg. Matinring & MCC 01 & 2012 \\
\hline $\begin{array}{l}\text { Pekendekan- } \\
\text { Sabbang }\end{array}$ & Dg. Matinring & MCC 02 & 2012 \\
\hline
\end{tabular}


photometer, NIR Systems Inc. Silver Springs MD) at the wave length of 400-2500 nm interval $2 \mathrm{~nm}$. Calibration of the aquipment was carried using modified partial least square regression. Data of fat content then classified high $(>55 \%)$, moderate $(52.3-55 \%)$ and low $(\leq 52.2 \%)$ according to Khan et al. (2008).

Evaluation for CPB resistance was observed based on the severity damage of pod sample with criteria healthy (no symptom), light (unextractable beans $<10 \%$ ), moderate (unextractable beans $10-<50 \%$ ) and heavy (unextractable beans $>50 \%$ ). The total assessed samples were 5,749 pods of MCC 01; 4,917 pods of MCC 02 and 6,981 pods of Sulawesi 01 . According to the assessment criteria yield losses (Y) was calculated based on Wardani et al. (1997) as bellow:

$\mathrm{Y}=-0.0210+0.1005 \mathrm{I}$

$\mathrm{Y}$ is yield losses, $\mathrm{I}$ is the score of intensity damage due to CPB.

$\mathrm{I}=[(0 \mathrm{x}$ pods number with healthy category $)$ $+(1 \mathrm{x}$ pods number with light damage category $)+(3 \mathrm{x}$ pod number with moderate damage category $)+(9 \times$ pods number with heavy damage category)]/(number of observed pods).

The resistance was classified according to the yield losses with criteria of resistant (0-20\%), moderate resistant ( $>20-40 \%)$, moderate susceptible ( $>40-60 \%)$, susceptible $(>60-80 \%)$ and highly susceptible $(>80 \%)$.

PPR incidence was calculated based on number of infected pod due to Phytophthora infection per tree during the evaluation time. Intensity of PPR incidence is the proportion of infected pods divided by total observed pod then be classified as resistant (0-20\%), moderate resistant $(>20-40 \%)$, moderate susceptible $(>40-60 \%)$, susceptible $(>60-80 \%)$ and highly susceptible ( $>80 \%)$.
To confirm the field resistance, the detached pods of the tested clones were also tested by using artificial inoculation method at the Laboratory of Phytopathology of ICCRI refer to the method reported by Susilo \& Anita-Sari (2014). For this test, the standard clones for resistance (Sca 6 and ICCRI 03) and susceptible (TSH 858) were also tested. The resistance was evaluated based on lession size due to P. palmivora infection during 7 days after inoculation.

Damage severity due to VSD infection was measured using score system in the scale of $0-6$ according to Susilo \& AnitaSari (2011). Evaluation was carried out during dry season (August-September 2013). Based on mean score the plants were classified for their resistance with category of resistant $(0-\leq 2)$, moderate resistant $(>2-\leq 3)$, moderate susceptible $(>3-\leq 4)$, susceptible $(>4-\leq 5)$ and highly susceptible $(>5)$.

Variance analysis was subjected to yield data $(\mathrm{kg} /$ tree) then followed by stability analysis according to Eberhart \& Russel (1966). Data for this analysis was collected from the sampled farm as replications. Due to the limitation of sampled farms for representing clone type, plant age and three replications, data were collected from the farm in the year of planting in 2008-2010.

\section{RESULT AND DISCUSSION}

Analysis of variance for yield indicated that there was no significant difference in yield between the tested clones (Table 2). This result confirmed that yield of locally selected clones of MCC 01 and MCC 02 was not significantly different with Sulawesi 01 as control. However, the yield potency of MCC 01 and MCC 02 was higher than Sulawesi 01 which means that the two clones would provide more benefit impact. That potency was also higher than ICCRI 03 and 
ICCRI 04 both of which were previously released as the resistant clones to Phytophthora pod rot (Suhendi et al., 2005). There were also no significant effect of plant age and no interaction between plant age and clone on yield performance which will be more influenced by genetic factor than by plant age or their interaction. Susilo (2011) reported that yield performance of cocoa hybrids was influenced by genetic factor also by altitude and climatic condition of the locations.

Stability parameters regarding deviation of regression of MCC 01 and MCC 02 were not significantly deviated to zero (Table 3 ) that enable to be interpreted that clone response to growth stage was linier. This result indicated that yield performance was stable during the stage of plant growth. Referring to the coefficient of regression it can be interpreted that the locally selected clones had general adaptability as the coeffi- cient was not different to zero in contrast to Sulawesi 01 clone which was significantly different to zero $(<1)$ that would be more adaptive to less favorable condition. In fact Sulawesi 01 clone grow well during all stages of growth in the so various agroclimatic conditions which indicating better adaptability in the less favorable environment. This results confirm that stability performance of the locally selected clones in term of growth stage showed the high potency of yield of those clones are stable expressed during all stage of plant growth.

Figure 1 and 2 show the high yielding performance of MCC 01 and MCC 02 in the field of North Luwu District area both of which are easly differentiated each other, especially with color performance of pod and flush. Those clones have been registered as local variety authorized by North Luwu District Goverment with register number of No.54/PVL/2013 and

Table 2. Variance analysis on the effect of cocoa clones and plant age to yield performance evaluated in farms in North Luwu, South Sulawesi

\begin{tabular}{|c|c|c|c|c|}
\hline Sources of variation & Degree of freedom & Sum square & Mean of sum square & $\mathrm{F}_{\text {tes }}$ \\
\hline Total & 8 & 20.72 & & \\
\hline Clone & 2 & 2.44 & 1.22 & $4.49^{\mathrm{ns}}$ \\
\hline Plant age + (clone $\mathrm{x}$ plant age $)$ & 6 & 2.75 & & \\
\hline Plant age (linier) & 1 & 1.75 & & \\
\hline Clone x plant age (linier) & 2 & 0.17 & 0.35 & $0.32^{\mathrm{ns}}$ \\
\hline Poolled deviation & 3 & 0.82 & 1.09 & \\
\hline - MCC 01 & 1 & 0.09 & 0.09 & $0.76^{\mathrm{ns}}$ \\
\hline - MCC 02 & 1 & 0.54 & 0.54 & $0.13^{\mathrm{ns}}$ \\
\hline - Sulawesi 01 & 1 & 0.19 & 0.19 & $0.27^{\mathrm{ns}}$ \\
\hline Poolled error & 26 & 18.29 & 0.70 & \\
\hline
\end{tabular}

Note: $\left(^{*}\right)$ significantly different, (ns) not significantly different based on Fisher test at $\alpha=5 \%$

Table 3. Yield potency and stability parameters according to Eberhart\&Russel (1966) observed in North Luwu (year of $2013-2014)$

\begin{tabular}{|c|c|c|c|c|c|}
\hline Clone & Yield (kg/ha/yr) & $\begin{array}{c}\text { Comparing to } \\
\text { Sulawesi } 01 \\
(\%)\end{array}$ & $\begin{array}{l}\text { Regression coeficient } \\
\text { (b) }\end{array}$ & $\begin{array}{l}\text { Regression deviation } \\
\qquad\left(\mathrm{S}_{\mathrm{di}}^{2}\right)\end{array}$ & Stability \\
\hline MCC 01 & $3,672.1$ & 132.5 & $1.28 \mathrm{~ns}$ & $-0.61^{\mathrm{ns}}$ & Stable \\
\hline MCC 02 & $3,132.2$ & 113.0 & $1.17 \mathrm{~ns}$ & -0.17 ns & Stable \\
\hline Sulawesi 01 & $2,772.3$ & & $0.57^{*}$ & -0.51 ns & Unstable \\
\hline
\end{tabular}




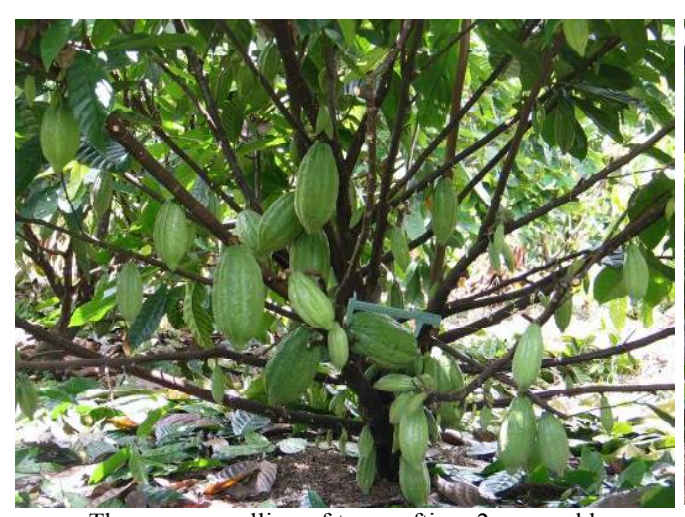

The grown seedling of top grafting, 2 years old

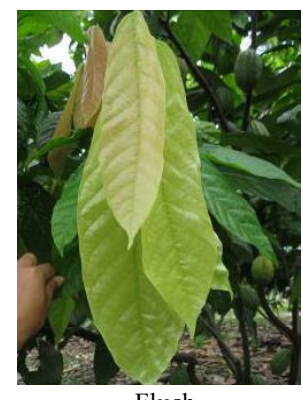

Flush

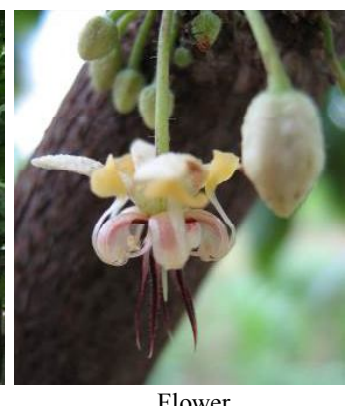

Flower

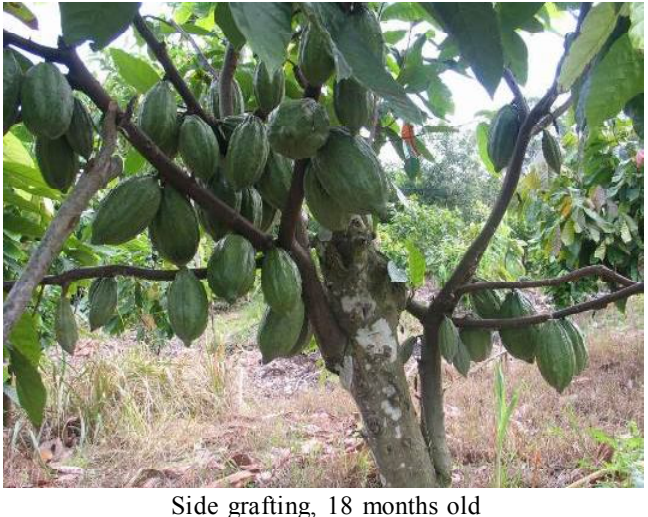

Side grafting, 18 months old

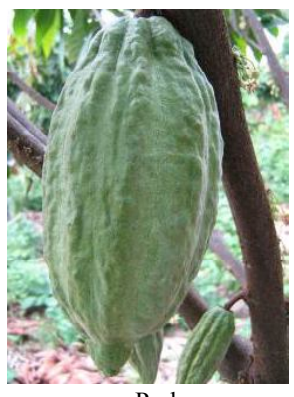

Figure 1. Performance of MCC 01 in the field indicating a high potency of yield

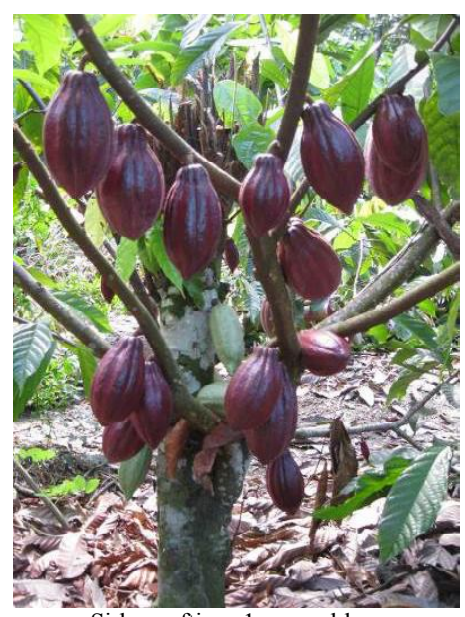

Side grafting, 1 year old

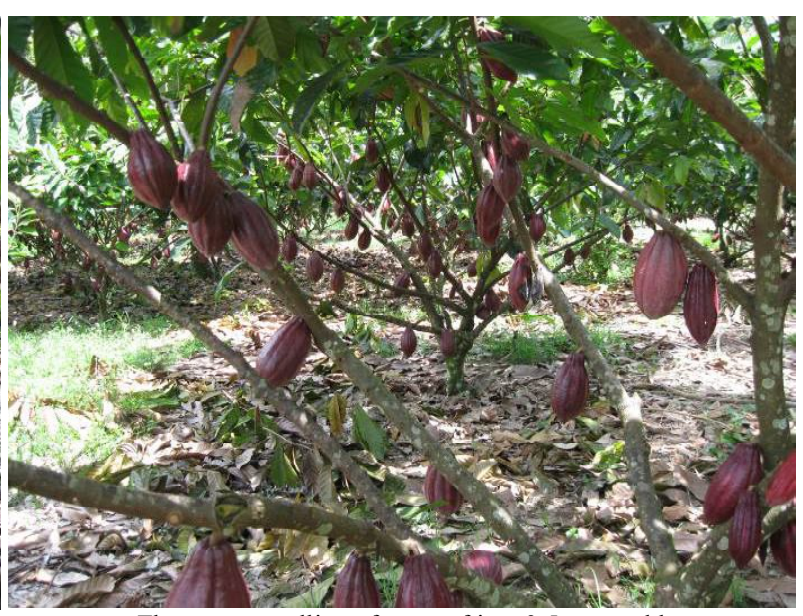

The grown seedling of top grafting, 3.5 years old

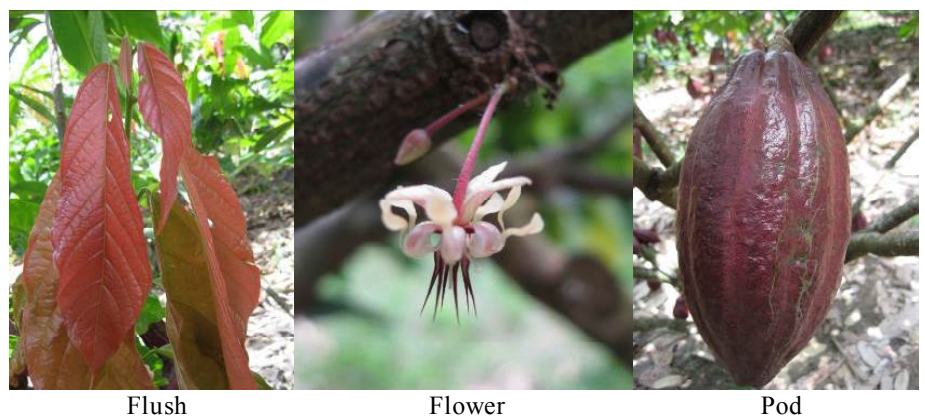

Figure 2. Performance of MCC 02 in the field indicating a high potency of yield 
No.55/PVL/2013 (Susilo, 2013). The agronomic characteristics of these clones performed more vigorous habitus with semi erect branches so the plants are easily managed, especially on pruning treatment. Some farmers also informed the clones were easly to be propagated vegetatively using top grafting or side grafting method explaining why farmers prefer developing those clones. A few clones selected in North Luwu showed phenomena of grafting incompatibility e.g. Phanter clone but MCC 01 and MCC 02 did not perform grafting incompatibility. Scion of these clones are easy grafted on to the rootstock of hybrid seedlings. Goenaga et al. (2015) reported that the propagation methods of cocoa clonal material did not affect on the variable of pod number in which genetic effect should be more considerred.

Yield stability evaluation in term of harvest time was carried out during all the year of assessment period. This information is very important to evaluate the locally selected clones of MCC 01 and MCC 02 would be classified as continuously bearing pods or not (biannual behavior). Phillips-Mora et al. (2013) characterized some of cocoa collection at CATIE which perform biannual behavior of the production as was also performed by fine-cocoa clones in East Java. In case of smallholder farming, the biannual behavior of production is not suitable on supporting the sustainability of farmers income all the year. In fact, cocoa was mostly preferred by smallholder farmers due to the continously production during all the year that significantly contribute to farmers income. The results indicated that locally selected clones of MCC 01 and MCC 02 continuously bear pods all months of the year of evaluation period with peak season of harvest in MayAugust (Figure 3). The behavior of continuous bearing pods is very useful to support the sustainability of farmers earn whose income mainly depend on cocoa.

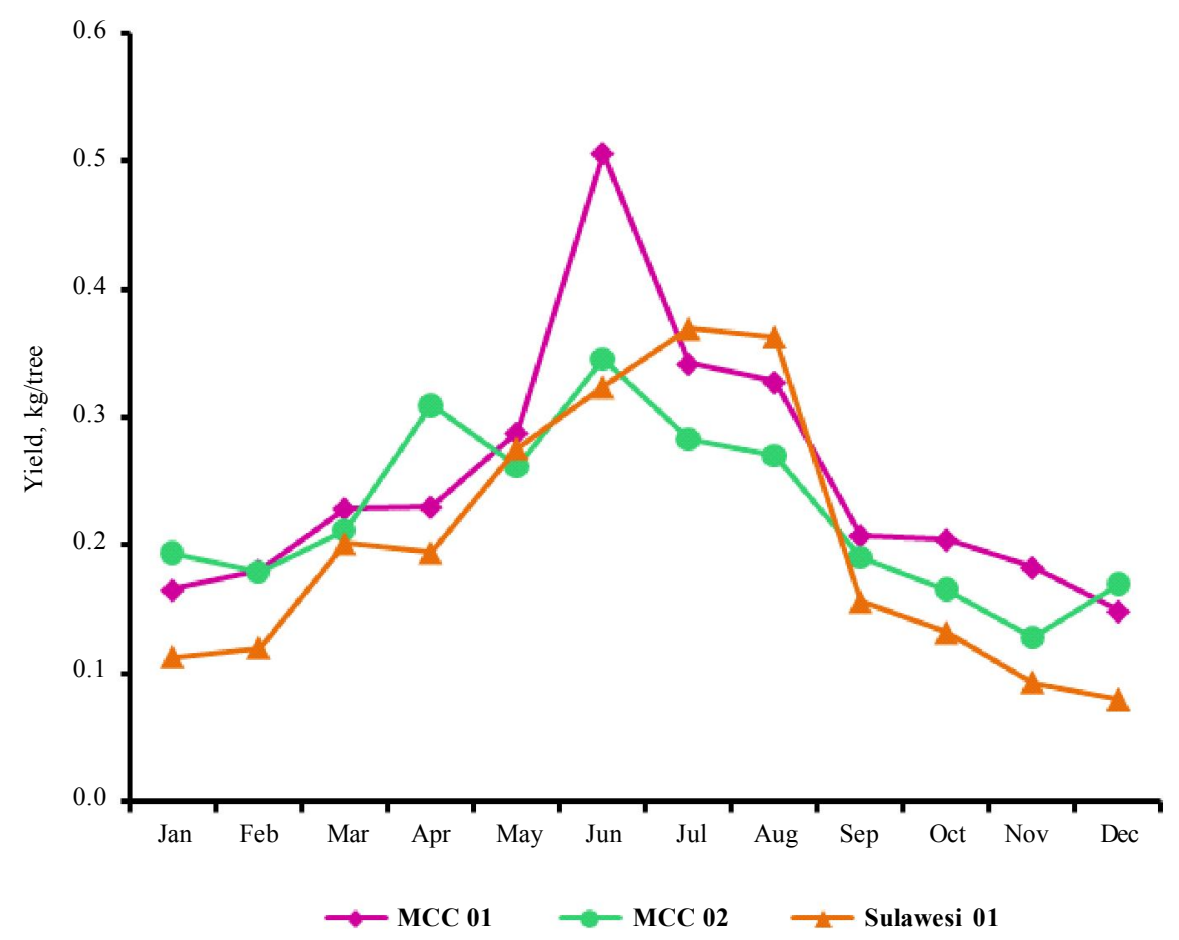

Figure 3. Monthly distribution of yield the locally observed cocoa clones in North Luwu (April 2013April 2014). 


\section{Pest and diseases resistance}

Field evaluation on CPB, VSD and PPR resistance indicated that MCC 01 and MCC 02 clones had good resistance to main pest/ diseases (Table 4). Based on the data of yield losses due to CPB infection, it is shown that MCC 02 had the best resistance to CPB (yield losses 3.94\%) while MCC 01 had moderately resistance to CPB (yield losses $20.96 \%$ ). Comparing to the data from the previous studies indicate the yield losses due to $\mathrm{CPB}$ of the susceptible clones reached up to $66 \%$ (Susilo et al., 2008) and $>80 \%$ Wiryadiputra et al. (1994) that confirm the two clones had better resistance to CPB. Factually in field, farmer's preference to MCC 02 was due to its resistance to CPB better than Sulawesi 01.

According to plant damage score due to VSD infections indicated that MCC 01 and MCC 02 had similar resistance to Sulawesi 01 with score less than 2.0. In an endemic area of VSD, susceptible trees would be very difficult to stand for live and producing pods. Susilo \& Anita-Sari (2011) reported that the intensity of died plants in susceptible hybrids reached up to $>50 \%$. The preference of cocoa farmers

Table 4. Severity damage intensity due to field infection of CPB, VSD and PPR of MCC 01 and MCC 02 clones assessed in Nort Luwu District area

\begin{tabular}{lccc}
\hline Clone & Yield lossess due to CPB, \% & Mean score of VSD damage & Intensity of Phytophthora pod rot, \% \\
\hline MCC 01 & 20.96 & $1.12 \pm 0.79$ & $1.15 \pm 0.56$ \\
MCC 02 & 3.94 & $0.71 \pm 0.54$ & $1.08 \pm 0.55$ \\
Sulawesi 01 & 9.29 & $0.77 \pm 0.52$ & $2.58 \pm 2.91$ \\
\hline
\end{tabular}

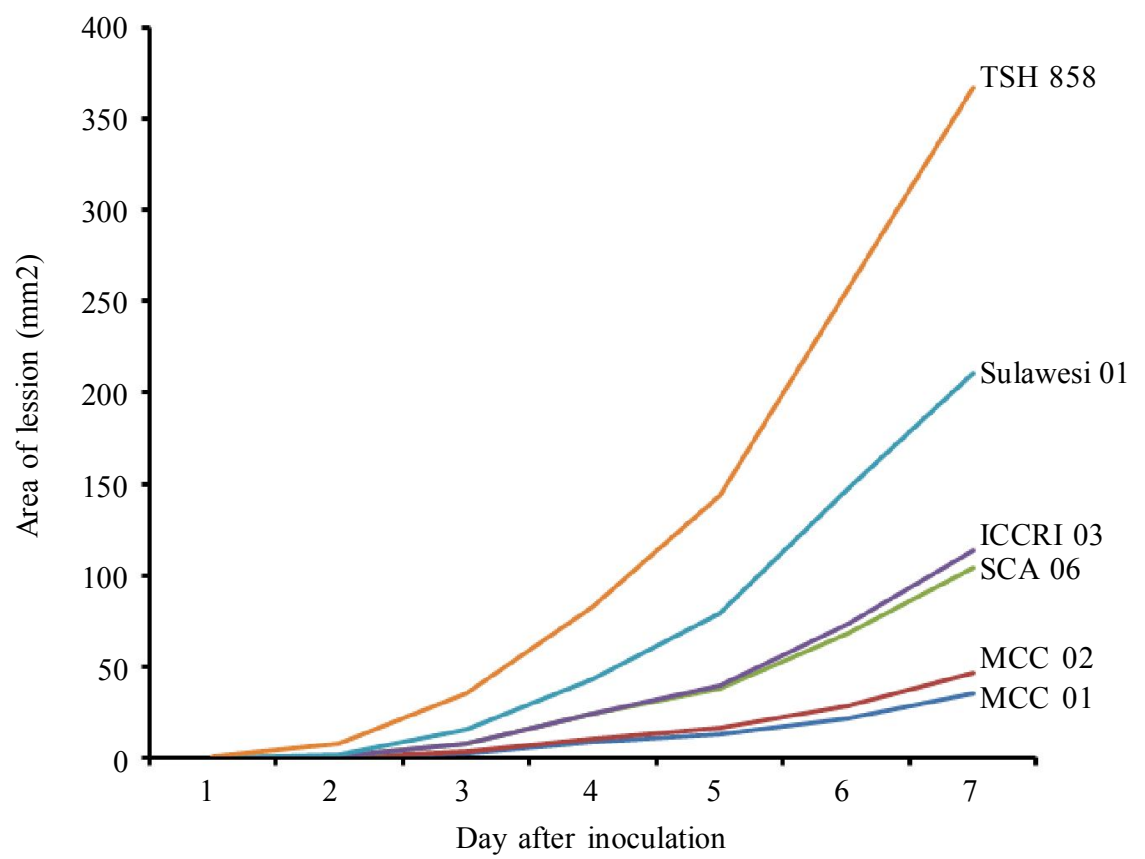

Figure 4. Development of lesion size during first 7 days after inoculation of $P$. palmivora between MCC 01 and MCC 02 with others tested clones with different level on PPR resistance. 
for developing MCC 01 and MCC 02 as clonal material was due to their resistance to VSD.

Intensity of PPR incidence on the locally selected clones was about $1 \%$ which indicated that those clones had good resistance to $P$. palmivora. This result was in parallel with the laboratory test in which MCC 01 and MCC 02 showed resistance to P. palmivora with the lesion size was less than the resistant clones of Sca 6 and ICCRI 03 (Figure 4). The present result indicated that no significant difference between MCC 01 and MCC 02 clones and resistant clones of Sca 6 and ICCRI 03 and significantly different with TSH 858 the susceptible one. According to this results it could be concluded that MCC 01 and MCC 02 clones had good resistance to $P$. palmivora.

\section{Bean quality}

Table 5 shows the potency of bean quality of the locally selected clones compared to Sulawesi 01 . The data indicated that the locally selected clones performed bigger size of dry beans than Sulawesi 01 which fulfill the AA classification according SNI (Indonesian standard for cocoa bean quality). This of bean size potency was similar to that of ICS 60 and UIT 1 which had bean size potency of 1.67 and $1.64 \mathrm{~g}$ per dry bean respectively which is the standard for big size of cocoa bean (Iswanto et al., 2001). However, the potency of fat content are low, namely less than $50 \%$, meanwhile up to now cocoa grinders still accept this quality regarding the fat content as Sulawesi 01 was used. This results had high potency for larger bean size than previous recommended clones of

Table 5. Yield component of MCC 01, MCC 02, and Sulawesi 01 observed in North Luwu

\begin{tabular}{|c|c|c|c|c|c|}
\hline Clone & $\begin{array}{l}\text { Dry weight bean } \\
(\mathrm{g})^{1)}\end{array}$ & Shell content, \% & $\begin{array}{l}\text { Nib fat content } \\
(\%)\end{array}$ & $\begin{array}{c}\text { Bean number } \\
\text { per pod }\end{array}$ & Pod index \\
\hline $\mathrm{MCC} 01$ & $1.61 \pm 0.36$ & $15.9 \pm 2.16$ & 49.67 & $38.3 \pm 5.17$ & 14.3 \\
\hline MCC 02 & $1.75 \pm 0.43$ & $12.0 \pm 1.62$ & 49.20 & $42.8 \pm 8.71$ & 14.7 \\
\hline Sulawesi 01 & $1.10 \pm 0.16$ & $17.7 \pm 2.87$ & 47.80 & $40.3 \pm 8.98$ & 23.6 \\
\hline
\end{tabular}

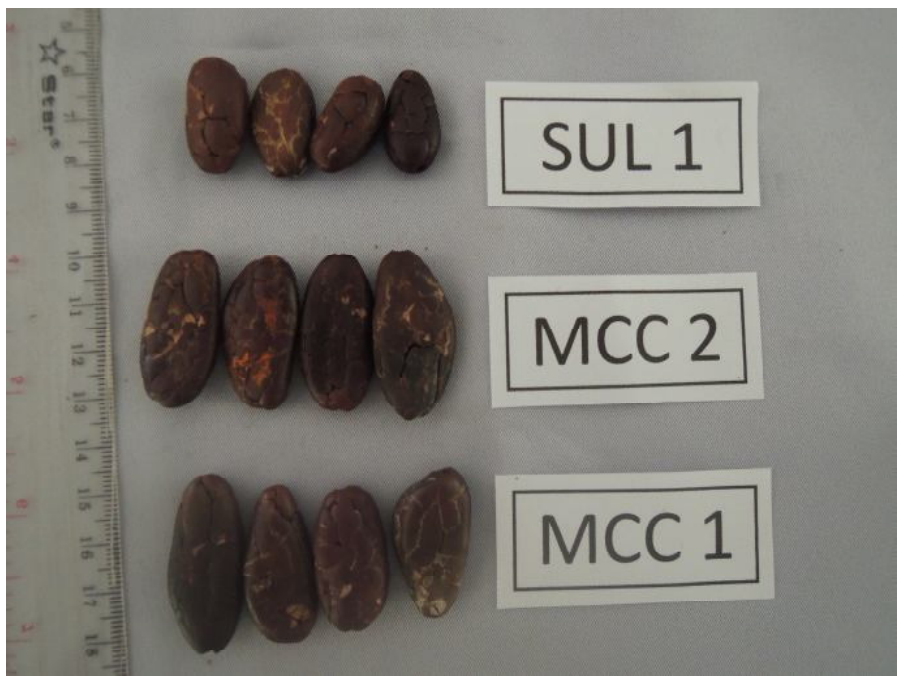

Figure 5. Nib size of MCC 01, MCC 02 and Sulawesi 01 
Sulawesi 01.

Referring to their high potency of yield, resistance to pest and diseases and bean quality, the locally selected clones of MCC 01 and MCC 02 were released as the recommended planting materials based on degree of Ministry of Agriculture No.1083/Kpts/SR.120/10/2014 and No.1082/Kpts/ SR.120/10/2014, respectively (Susilo, 2015). Those clones can be developed in monoclonal system due to both of which are self compatible, however it is recommended to plant in polyclonal system especially planted with others recommended clones such as Sulawesi 01 and Sulawesi 02 to increase horizontal resistance. MCC 01 and MCC 02 clones have to be propagated vegetatively by using top grafting method, budding or in vitro culture using somatic embryogenesis methods. Those clones are suitable planted in the area with agro-climatic condition similar to North Luwu District area. The plant variety which were participatory selected have a specific adaptation to agroclimatic condition refer to the local environment in where it was developed (Ceccarelli \& Grando, 2007).

\section{CONCLUSION}

The observation of yield performance of the locally selected clones in North Luwu District indicate that clones of MCC 01 and MCC 02 have yield potency of 3,682 kg/ ha/yr and 3,132 kg/ha/yr, respectively, higher than Sulawesi 01 of $2.772 \mathrm{~kg} / \mathrm{ha} / \mathrm{yr}$. Performances of the yield are stable along the plant age. Field resistance evaluation indicate that MCC 01 performs moderate resistance to $\mathrm{CPB}$, resistance to VSD and resistance to Phtytophthora pod rot, while MCC 02 performs resistant to $\mathrm{CPB}$, resistance to VSD and resistance to Phtytophthora pod rot. The bean size of MCC 01 and MCC 02 are 1.75 and $1.60 \mathrm{~g} /$ dry bean, respectively, which fulfill AA qualification according to SNI.

\section{ACKNOWLEDGMENT}

The authors wish to thanks the Director of ICCRI and the Mayor of North Luwu District c.q. Head of Dinas Kehutanan dan Perkebunan who facilitating the funding for field observation, Mr. Hussin Purung (Mars Inc.) for supporting fat analysis process, the extension servive staff of Dinas Kehutanan dan Perkebunan North Luwu District for implementing the field observation.

\section{REFFERENCES}

BPS Sulsel (2013). Laporan Hasil Sensus Pertanian Tahun 2013. Badan Pusat Statistik Provinsi Sulawesi Selatan, Makassar, 36 p.

Ceccarelli, S. \& S. Grando (2007). Decentralizedparticipatory plant breeding: an example of demand driven research. Euphytica, 155, 349-360.

Ditjenbun (2008). Pedoman Umum Gerakan Peningkatan Produksi dan Mutu Kakao Nasional 2009-2011. Direktorat Jenderal Perkebunan, Jakarta.

Ditjenbun (2012). Arah kebijakan pengembangan kakao menjelang tahun 2025. Makalah Simposium dan Ekspo Kakao 2012, Padang 6-9 November 2012.

Eberhart, S.A. \& W.A. Russell (1966). Stability parameters for comparing varieties. Crop Science, 6, 36-40.

Goenaga, R.; M. Guiltinan \& S. Maximova (2015). Yield performance and bean quality traits of cacao propagated by grafting and somatic embryo-derived cuttings. HortScience, 50, 358-362.

Iswanto, A.; D. Suhendy \& A.W. Susilo (2001). Hasil seleksi dan persilangan genotipe penghasil biji kakao lindak dan mulia. Warta Pusat Penelitian Kopi dan Kakao 17, 46-60.

Khan, N.; L.A. Motilal; D.A. Sukha; F.L. Bekele; A.D. Iwaro; G.G. Bidaisee; P. Umaharan; L.H. Grierson \& D. Zhang (2008). Variability of butter fat content in 
cacao (Theobroma cacao L.): combination and correlation with other seedderived traits at the International Cocoa Genebank, Trinidad. Plant Genetic Resources: Characterization and Utilization. 1-12.

Phillips-Mora; A. Arciniegas-Leal; A. MataQuirós \& J.C. Motamayor-Arias (2013). Catalogue of cocoa clones selected by CATIE for commercial plantings. Tropical Agricultural Research and Higher Education Center (CATIE). Cocoa Genetic Improvement Program, Turrialba, Costa Rica.

Pokoe, N.D.; J.A.K.N_Goran; P.H. Lachenaud; A.B. Eskes; J.C. Motamayor; R. Schnell; M. Kolesnikoa-Allen; D. Clément \& A. Sangare (2009). Recurrent selection of cocoa populations in Cóte Ivoire: comparative genetic diversity between the first and second cycles. Plant Breeding, 128, 514-520.

Suhendi, D.; S. Mawardi \& H. Winarno (2005). Daya hasil dan daya adaptasi beberapa klon harapan kakao lindak. Pelita Perkebunan, 21, 1-11.

Susilo, A.W. (2011). Analisis stabilitas dayahasil beberapa hibrida unggul harapan kakao (Theobroma cacao L.) pada lokasi tumbuh berbeda. Pelita Perkebunan, 27, 168-180.

Susilo, A.W. (2013). Peran petani dalam pengembangan klon-klon lokal Sulawesi. Warta Pusat Penelitian Kopi dan Kakao, 25, 1-6.

Susilo, A.W. \& D. Suhendi (2006). Identifikasi penyebaran klon kakao asal Malaysia di wilayah Sulawesi. Warta Pusat Penelitian Kopi dan Kakao Indonesia, 22, 20-27.
Susilo, A.W.; E. Sulistyowati; E. Mufrihati; A. Wahab; P. McMahon; P. Keane; D. Guest; S. Lambert \& A. Purwantara (2008). Selection cocoa clones which resistance to cocoa pod borer (Conopomorpha cramerella Snell.). Unpublished/Report. ACIAR.

Susilo, A.W. \& I. Anita-Sari (2011). Respons ketahanan beberapa hibrida kakao (Theobroma cacao L.) terhadap serangan penyakit pembuluh kayu (vascular-streak dieback). Pelita Perkebunan, 27, 77-87.

Susilo, A.W. \& I. Anita-Sari (2014). Evaluasi ketahanan beberapa klon kakao (Theobroma cacao L.) terhadap Phytophthora palmivora. Pelita Perkebunan, 30, 1-14.

Susilo, A.W.; I. Anita-Sari \& S. Mawardi (2013). Seratus tahun pemuliaan kakao di Indonesia. p. 110-121. In: T. Wahyudi, J.B. Baon; S. Abdoellah; Misnawi \& A.W. Susilo (Eds.). Prosiding Simposium Kakao 2012, Padang 5-8 November 2012.

Wardani, S.; H. Winarno \& E. Sulistyowati (1997). Model pendugaan kehilangan hasil akibat serangan hama penggerek buah kakao. Pelita Perkebunan, 13, 33-39.

Wiryadiputra, S.; E. Sulistyowati \& A. Prawoto. (1994). Teknik pengendalian hama penggerek buah kakao, Conopomorpha cramerella (Snellen). Lokakarya Penanggulangan Hama PBK di Indonesia. Jember, 8 Februari 1994.

$$
* * 0 * *
$$

